\title{
Plant Succession in the Rocky Mountain Trench: Influence of Historical Factors
}

\author{
"Today's ecosystems are the integration of all past and present inputs \\ and processes that have influenced them."
}

\author{
By Brian M. Wikeem and Timothy J. Ross
}

$T^{\mathrm{T}}$ here are approximately 250,000 ha of land in the Ponderosa Pine and Interior Douglas-fir biogeoclimatic zones in the Rocky Mountain Trench and adjoining side-valleys between the U.S. border and Golden, British Columbia (BC) (Figure 1).

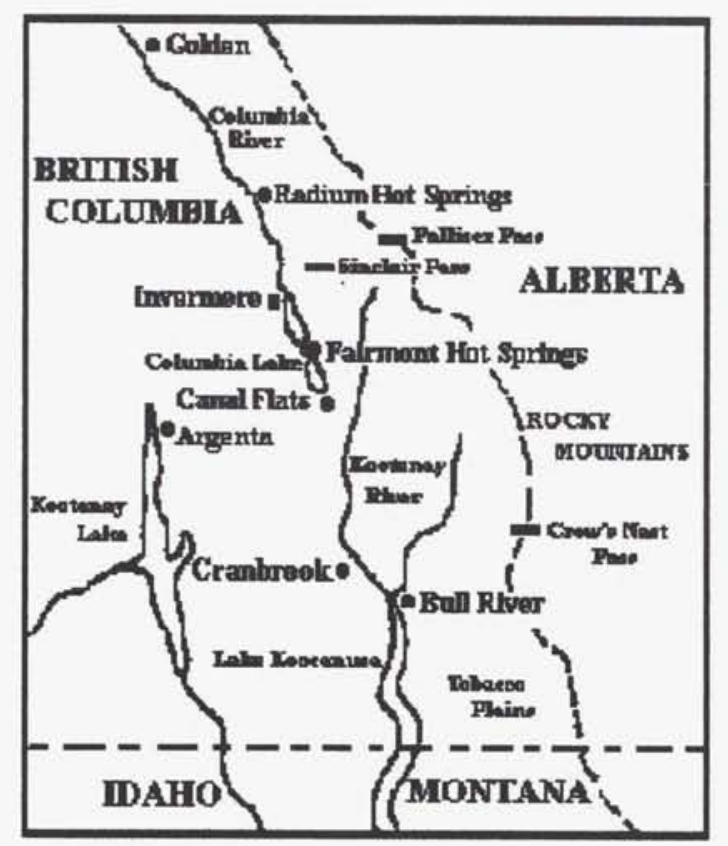

Figure 1. The Rocky Mountain Trench from Golden to the Tobacco Plains in southeastern British Columbia.

Under climax conditions, the Ponderosa Pine Zone is dominated by ponderosa pine with an understory of rough fescue, Idaho fescue, bluebunch wheatgrass and a variety of forbs and shrubs. In the drier parts of the Interior Douglas-fir Zone, Douglas-fir is the principal tree with an understory of bluebunch wheatgrass, rough fescue, and Richardson's needlegrass combined with forbs such as western yarrow and timber milkvetch. In wetter parts of the zone, pinegrass is the dominant grass at higher stages of succession.

These dry forests provide habitat and forage for whitetail deer, mule deer, elk, and cattle. Numerous sources of disturbance have modified both these forest types historically, which have had significant effects on plant communities and the forage resource in the Rocky Mountain Trench.

\section{Pre-European Fire}

Historically, lightning-caused fire has been prevalent in the Ponderosa Pine and Interior Douglas-fir Zones and is regarded as a natural part of the environment. Low-intensity ground fires, returning at 5-50 year intervals, maintained ponderosa pine and Douglas-fir forests in the Trench as a mosaic of grassland, open forest, and dense forest.

George Simpson of the Hudson Bay Company arrived in the Trench in the summer of 1841 and traversed the same area that David Thompson had explored about 30 years earlier. While Thompson commented on the fine timber in the area, Simpson found "the country was on fire, the sun shone like a blood red dice in the sky and every horse raised such a cloud of dust as almost to conceal itself from view". The area he described was north and south of present day Fairmont Hot Springs.

Aboriginal fires also played a role in shaping and maintaining plant communities in the Trench historically. Evidence from the Flathead region of the Pacific Northwest U.S. indicates that the introduction of horses considerably intensified native burning, especially as horse herds became larger. Although the Kootenay Indians respected fire, early narratives suggest that they deliberately set forest fires to create horse pasture.

\section{Historical Horses}

The exact date that horses arrived in the East Kootenay is unknown. Horses, however, are believed to have been 


\begin{tabular}{|ll|}
\hline \multicolumn{2}{|l|}{ Common and Scientific Names of Plants and Animals } \\
Grasses & \\
Bluebunch wheatgrass & Agropyron spicatum \\
Idaho fescue & Festuca idahoensis \\
Pinegrass & Calamagrostis rubescens \\
Prairie Junegrass & Koeleria cristata \\
Rough fescue & Festuca scabrella \\
Richardson's needlegrass & Stipa richardsonii \\
Forbs & \\
Timber milkvetch & Astragalus miser \\
Western yarrow & Achillea millefolium \\
Trees and Shrubs & \\
Bearberry & Arctostaphyalus uva-ursa \\
Douglas-fir & Pseudotsuga menziesii \\
Ponderosa pine & Pinus ponderosa \\
Animal Species & \\
Bison & Bison bison \\
Cattle & Bos taurus \\
Elk & Cervus elephus \\
Horse & Equus caballus \\
Mule deer & Odocoileus hemionus \\
Whitetail deer & Odocoileus virginianus \\
Plant nomenclature follows Hitchcock and Cronquist (1973). & \\
\hline
\end{tabular}

present along the western slope of the Rocky Mountains as early as 1680 and introduced to the Flatheads and Nez Perce between 1720 and 1730 .

The Kootenay Indians definitely had horses by 1792 . Peter Fidler, Hudson Bay Company surveyor, met Kootenays in the foothills of Alberta in 1792 who were trading horses with the Peigan Indians of the Great Plains. Moreover, David Thompson reported seeing herds of "wild" horses, trading the Kootenay Indians for horses, eating horsemeat, and chasing feral horses throughout the Trench during his explorations from 1807 to 1811.

The size of horse populations in the Trench from 1800 to 1900 is impossible to discern. James Hector of the Palliser Expedition, however, encountered Kootenays near Columbia Lake in 1859. "They had a band of about 500 horses, many of them being beautiful animals and as wild as deer". By the $1880 \mathrm{~s}$, the natives around Joseph's Prairie (present day Cranbrook) had about 2,000 horses and 500 head of cattle. Additionally, an early Indian agent on the Tobacco Plains reported 5,000 horses grazing there that belonged to natives on both sides of the International Boundary Line. Although horses greatly enhanced aboriginal mobility, it is difficult to determine the extent and magnitude of ecological change attributable to horses in the Trench but historical numbers suggest they could have had an early impact.

\section{Discovery of Gold}

Gold was discovered at Wild Horse Creek near Cranbrook in 1863 and hundreds of miners headed for this new El Dorado. By 1865, between 5,000 and 8,000 men were mining in the district. Although no beef was available, about 100 sheep were imported in 1865 to feed the miners. Cattle were driven from Salt Lake City, Utah; and Lewiston, Idaho to Wild Horse Creek during 1866-1867, while other cattle were brought in from Washington State. In addition, some of the early cattle drives came from Argenta on Kootenay Lake to Windermere over the "Beef Trail" through Earl Gray Pass.

Mining interests in the Cariboo began to dwindle after 1865 and attention focused on the mines in the Kootenays. A new market for Okanagan and Similkameen beef had to be found after the collapse of the Cariboo mining boom and cattle were driven over the old Dewdney Trail to the new gold fields in the East Kootenay. In addition to cattle drives, all merchandise was packed into the area by mule and horse trains that were pastured on East Kootenay ranges during, and between, trips.

\section{Domestic Livestock}

Immigrants under the leadership of James Sinclair brought in the first cattle in the Trench from the Red River Settlement at Fort Garry in 1841. They brought horses, cattle and dogs through Sinclair Pass (present day Radium Hot Springs) descending the Cross and Kootenay rivers to Columbia Lake. A second group from Fort Garry brought cattle and horses in 1854. When they arrived at McGillivary's Portage (present day Canal Flats) they found "plenty of fine bunch grass for their stock" and encountered Kootenay Indians with whom they traded some of their cattle for horses. James Hector reported meeting Kootenays south of Columbia Lake in 1859. In addition to about 500 horses, they also had 10 or 12 cows.

Although the first land acquisitions occurred as early as 1867 , early settlement in the Trench did not begin until the 1880 s. During this period, numerous ranches were established from Invermere to the U.S. border. Typically, ranches ran between 50 and 125 cattle but several ranchers had herds ranging from 200 to 300 head. James McKay, an early rancher near Invermere, had several hundred cattle by the late 1880 s and over 1,000 cattle in the early 1900 s.

Not all ranches ran cattle, at least in the beginning. For example, A.B. Fenwick purchased land in 1886 on the Kootenay River bottomlands between Fort Steele and Bull River. For many years, however, Fenwick used the land more for grazing his packhorses and harvesting native grass than for farming and raising cattle. The number of pack animals living in the Trench at that time is 
unknown but they were another grazing impact on local rangeland until the railroad was completed in the early 1900 s.

Grasslands in the East Kootenay have been grazed by domestic livestock since the Kootenay Indians fed their horses on native grasslands in the area. From the late 1800 s to the mid-1940s, cattle, and other livestock numbers, increased in the area. Indeed, sheep were brought to the Trench from California to Bummers Flats in about 1910. Between 1945 and 1954 beef cattle numbers averaged approximately 9,000. Horses still remain a factor on East Kootenay rangelands, albeit a minor aspect, as most ranchers and guide outfitters have horses for their operations.

\section{Railway Building and Fires}

More horses and cattle were moved into the East Kootenay between 1897 and 1915 for the Canadian Pacific Railroad (CPR) construction through the Crows Nest Pass and north to Windermere. During this era, more than 5,000 men worked on the railroad and about 1,000 teams of horses were employed. Shops in Cranbrook, Fernie, and Moyie handled from 300 to 400 cattle a month, mostly herded from Alberta, to feed the railway crews.

The Kootenay Central Branch of the CPR reached Bull River by 1911 . By then, over 200,000 railway ties had been milled for construction of the line further north. Although Bull River was the center of operations for tie production, logging extended further north to Skookumchuck Prairie and beyond, and logs were boomed down the Kootenay River for processing at the Bull River mill.

Both the direct effects of logging, and the subsequent fires that followed, contributed to opening up large areas of range for cattle, horses, and wildlife throughout the southern part of the Trench. Numerous fires occurred between 1914 and 1931 as the litter of limbs, treetops and broadaxe chips dried and became extremely flammable. Some fires, like the fire of 1914 , started in the logging camps but steam locomotives throwing out sparks along the railway ignited others. Many of these fires consumed large volumes of standing timber and covered extensive areas of the landscape. The last large fire in 1931, for example, burned about 81,000 ha $(200,000 \mathrm{ac})$ of forestland alone.

\section{Wildlife}

Ungulate populations have probably been variable before, and after, Europeans entered the Rocky Mountain Trench. Early accounts by David Thompson and the Palliser Expedition indicate that elk and deer were not numerous during the period of exploration and both parties complained of food shortages to the point of near starvation. Additionally, the Kootenay made up to three trips annually to Alberta for buffalo meat because big game was scarce in the Trench, even before Europeans were present.

Elk may have been historically abundant in the Trench. In 1859, James Hector reported "Elk or wapiti must at one time have been very numerous in this district, as we saw a great many antlers lying on the ground, and sometimes the Indians had piled them in heaps of 50 or 60 together but the open nature of the woods, and the limited range, excepting up and down the valley, must have made them an easy prey to the Indians as soon as they acquired firearms." Conversely, he also commented, "We have not seen a single track of an elk yet in the valley but only a few of the smaller deer. "Walter Moberly, surveyor for the Government of Canada, also reported seeing large piles of elk antlers scattered over the country near Invermere in 1866.

Severe winters dramatically reduced elk populations throughout British Columbia in the mid- and late-1800s, including the East Kootenay. Native legend indicates that the winter of $1865-66$ was very cold with a snowfall

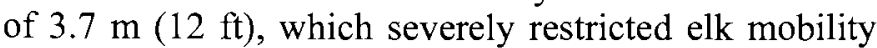
and they died by the hundreds. A series of severe winters during the 1880 s further reduced elk populations, but from about 1900 to the 1950 s, elk and deer populations began to increase. Part of this expansion likely resulted from the abundance of forage and new habitat created by the fires from 1914 to 1931 .

Mule deer and possibly whitetail deer were apparently more abundant than elk when Europeans first arrived in the Trench. David Thompson mentions killing deer for meat from 1807 to 1811 more often than elk but he still complained that game was scarce. Although mule deer and whitetail deer were plentiful from the 1860 s to the 1960 s, populations of both species increased dramatically during the 1940s and 1950s. Undoubtedly, these increases contributed to further pressures on the range resource.

\section{Feral Horses}

Feral horses have been in the Trench since at least 1800 and probably earlier. In 1809 , David Thompson reported that he "spent time chasing after some of the feral horses that grazed the foothills above the lakes" [likely Lake Windermere and Columbia Lake]. According to the Kootenays, these horses once belonged to members of their tribe who died from smallpox in the 1780s.

During the 1940s and 1950s powered farm and logging equipment replaced most of the horses used by these industries and many horses were turned loose on the range. At the same time, ranchers were increasing their cattle herds, taking advantage of the abundant range created by fires. By then, it was apparent that range condition was deteriorating and the Forest Service 
decided to remove about 5,000 feral horses from the range. Roundup corrals were constructed and some horses were trapped and sold. Others were too wild and were shot on the range. By the early 1950s, most of the feral horses were gone and their place taken by domestic cattle and elk.

\section{Genesis of a New Paradigm}

From 1846 to the early 1920 s almost all grazing in British Columbia was confined to the grasslands although some of the low-elevation open forests had been grazed by the 1890 s. Throughout this period, grazing was unregulated and by the turn of the century most of the grasslands were overgrazed while $90 \%$ of the forested summer range remained unused. Although the "Grazing Act", which became law in March 1919, provided a legislative framework for administrative control over the range, it would be some time later before scientific range management principles were applied.

In 1930 , concern over the depleted condition of the interior rangelands led to the Grazing Committee Enquiry. The committee recommended that the Forest Branch should have more authority to deal with range issues and a need for range research was also identified. By 1935 a Substation of the Dominion Range Experiment Station at Manyberries, Alberta was established at Kamloops. Several range surveys were also conducted between 1930 and the mid-1950s, which confirmed that most of the grasslands were depleted. Among these, a soil survey in the East Kootenay in 1956, declared that most of the grasslands in the Trench were overgrazed and recognized the need for better management. The removal of feral horses provided an opportunity to manage the range properly, but competition between cattle and wildlife was becoming a problem.

From 1945 to 1956 the Grazing Division slowly grew in size and geographic distribution and by 1956 there were 8 professionals located at Kamloops, Williams Lake, Prince George, and Nelson. Unfortunately, progress was slow, and in 1956, the Sloan Report on the Forest Resources of British Columbia concluded that district staffing levels were still insufficient to administer both timber and grazing problems on Crown land. Additionally, Mr. Wilf Pendray, Commissioner of Grazing, concluded that an up-to-date inventory was fundamental to proper range management, and that each range unit should have a complete, easily-applied management plan. These events heralded the beginning of a modern era of range management in the East Kootenay, and British Columbia, based upon scientific principles, and range conditions began to improve on selected grasslands.
About the authors: Ross is a certified range consultant, Ross Range and Reclamation Services, P.O. Box 283, Cranbrook, BC, Canada, V1C 4H8; Wikeem is a natural resource consultant, Solterra Resources Inc., 4611 Westsyde Road, Kamloops, BC, Canada, V2B 8N3. At the time of research, Wikeem was Range Scientist, Research Branch, BC Ministry of Forests, Kamloops, BC and. Ross was Range Ecologist, Research Branch, BC Ministry of Forests, Cranbrook, $B C$.

This project was supported by the Sustainable Environment Fund, the Forest Resources Development Agreement, the Beef Cattle Industry Development Fund and the Kootenay/Boundary Grazing Enhancement Program.

\section{References and Other Readings}

Belyea, Barbara. 1994. Columbia journals-David Thompson. McGill-Queen's University Press, Montreal. $336 \mathrm{p}$.

Braumandl, T.F. and M.P. Curran. 1992. A field guide for site identification and interpretation for the Nelson Forest Region. BC Min. Forests, Nelson, B.C.

Casselman, V. 1998. Ties to Water: The history of Bull River in the East Kootenay (Fourth Edition), Friesens Corporation, Altona, Man. 275p.

Graham, C. 1963. This was the Kootenay. Evergreen Press, Vancouver, B.C.

Heady, Harold. 1973. Structure and function of climax. pp. 73-80 In: Proc. $3^{\text {rd }}$ Workshop of the United States/Australian Rangeland Panel, Tuscon, Ariz. Society for Range Manage., Denver, Colo.

Hitcheock, C.L. and A. Cronquist. 1973. Flora of the Pacific Northwest. An illustrated manual. Univ. Wash. Press. Seattle, Wash. 730p.

Kelley, C.C. and P.N. Sprout. 1956. Soil survey of the upper Kootenay and Elk River Valleys in the East Kootenay district of British Columbia. Report No. 5 of the BC Soil Survey, Queen's Printer, Ottawa, Ont. 99 p.

Nisbet, Jack. 1994. Sources of the river. Tracking David Thompson across western North America. Sasquatch Book, Seattle, Wash. 280p.

Robbins G.W. 1993. Landscape and environment. Ecological change in the Intermountain Northwest. Pacific Northwest Quarterly 140-149.

Smyth, F.J. 1937. Tales of the Kootenays. J.J. Douglas Ltd. Vancouver, B.C.

Spry, I.M. 1968. The papers of the Palliser Expedition 1857 1860. The Champlain Society, Toronto, Ont. 581p.

Tyrrell, J.B. 1916. David Thompson's narrative of his explorations in Western North America. The Champlain Society. First Greenwood Reprinting (1968).

Whitfield, H.N. and R.D. Craig. 1918. Forests of British Columbia. Comm. Cons., Comm.on Forests, Ottawa. Pp. 64-65. 